\title{
THE CONSTITUTIONAL PROHIBITION OF BILLS OF ATTAINDER: A WANING GUARANTY OF JUDICIAL TRIAL
}

"There is no liberty, if the power of judging be not separated from the legislative and executive powers."

- Montesquiell, quoted in

The Federatist, No. 78

at 521 (Heritage ed. 1945)

ThE United States Constitution denies both Congress and the state legislatures the power to pass bills of attainder. ${ }^{1}$ The elements necessary to constitute a particular piece of legislation a bill of attainder are obscure. The deceptively simple definition of Cummings $v$. Missouri, ${ }^{2}$ the leading case,"a legislative act which inflicts punishment without a judicial trial" - has proved difficult of application. The case law is replete with split and irreconcilable decisions, largely revolving about the meaning of "punishment." 4 Moreover, recent opinions tend to brush off a bill of attainder argument with only the most superficial discussion of precedent.

1. U.S. Const. Art. I, $\$ \S 9,10$. For background, see 1 Watson, The Constitution of the United States 733-5 (1910).

Parliament and the American colonial legislatures had frequently visited punishment upon individuals without judicial trial. See, generally, 1 COoLEy, Constrututional Limirstrons 536 (8th ed. 1927); 2 Story, Comimentaries on the Constitution $\$ 1344$ (5th ed., Bigelow, 1891) ; Pound, Justice According to Law II, 14 CoL. L. Rev. 1, 1-12 (1914); Thompson, Anti-Loyalist Legislation During the American Revolution, 3 ILL. La REv. 81, 147 (1908) ; Annotation, 90 L. En. 1267, 1268-9 (1946).

2. 4 Wa1l. 277 (U.S. 1867).

3. Id. at 323. It goes without saying that there must be an act of the legislature. Yet the charge of bill of attainder has been leveled, unsuccessfully, against even a court's refusal to admit evidence, United States v. Gosciniak, 142 F.2d 240 (7th Cir. 1944); regulations promulgated by the Federal Communications Commission, American Brondcasting Co. v. United States, 110 F. Supp. 374 (S.D.N.Y. 1953) ; and revocation of a passport, Bauer v. Acheson, 106 F. Supp. 445 (D.D.C. 1952).

4. Compare Garner v. Board of Public Works, 341 U.S. 716 (1951), with Cummings v. Missouri, 4 Wall. 277 (U.S. 1867) ; Ex parte Hunter, 2 W. Va. 122 (1867), with E.x parte Garland, 4 Wall. 333 (U.S. 1867) ; Randolph v. Good, 3 W. Va. 551 (1869), zvith Green v. Shumway, 39 N.Y. 418 (1868).

5. Since United States v. Lovett, 328 U.S. 303 (1946), courts have tended to treat as trivial an objection that a statute is a bill of attainder. In American Communications Association v. Douds, 339 U.S. 382 (1950), the 31-page Court opinion devotes only two paragraphs near the very end to this question. In Garner v. Board of Public Works, 341 U.S. 716 (1951), the Court gives it three paragraphs. In several other recent decisions where the bill of attainder question would appear relevant, the Supreme Court has not even mentioned it. Wieman v. Updegraff, 344 U.S. 183 (1952) ; Adler v. Board of Education, 342 U.S. 485 (1952) ; Gerende v. Board of Supervisors, 341 U.S. 56 (1951).

The lower federal courts and the state courts usually dismiss the objection with only 
The prohibition of bills of attainder is one of several constitutional provisions aimed at maintaining the separation of governmental powers. ${ }^{b} \mathrm{By}$ barring legislatures from usurpation of judicial functions, ${ }^{7}$ the prohibition was intended to provide a "bulwark [to guard] personal security and private rights" from "the fluctuating policy which has directed public councils."8 Courts have pointed out that bills of attainder are usually products of "emergencies" when "necessity" is said to render existing laws and judicial trial inadequate to punish past delinquencies and to preserve community security." Drumhead justice dispensed by legislatures in such an atmosphere obviously lacks "any of the forms or safeguards of [judicial] trial." 10

\section{Methods of Identifying Victins}

It is well established that, in order to qualify as a bill of attainder, a statute must apply either to named individuals or to an easily ascertainable group.11 Parliamentary and colonial bills of attainder usually designated their victims by name ${ }^{12}$ or description. ${ }^{13}$ But the reported cases reveal that, since the adoption of the Constitution, an American legislature has only once been in-

a sentence or two. E.g., Inland Steel Co. v. NLRB, 170 F.2d 247 (7th Cir. 1948); National Maritime Union of America v. Herzog, 78 F. Supp. 146 (D.D.C.), aff'd fer curian on other gronnds, 334 U.S. 854 (1948); Shub v. Simpson, 196 MId. 177, 76 A.2d 332, appeal dismissed as noot, 340 U.S. 881 (1950); Thorp v. Board of Trustees, 6 N.J. 498, 79 A.2d 462 (1951); Huntamer v. Coe, 40 Wash. 2d 767, 246 P.2d 489 (1952).

6. See, generally, Wormuth, Legislatiz' Disqualifications as Bills of Atfair:der, 4 VAND. L. REv. 603, 603-05 (1951).

7. See Calder v. Bull, 3 Dall. $386,3 S 9$ (U.S. 179S); Burlsett v. MfeCarty, 73 Ky. 758, 760 (1866) ; Green v. Shumway, 39 N.Y. 418 , 421 (1868); 2 STory, Cossariranues on the Constitution $\$ 1344$ (5th ed., Bigelow, 1S91).

8. The Feneralist, No. 44 (Madison) at 299 (Heritage ed. 1945).

9. See Davis v. Pierse, 7 Minn. 13, 16 (1862) ; Green v. Shumway, 39 N.Y. 418, 422, 425 (1868) ; 2 Story, Counientartes on the Constitution $\$ 1344$ (5th ed., Bigelow, 1891).

On this very reasoning, some judges have made a point of criticizing the leading cases, Cummings v. Missouri, 4 Wall. 277 (U.S. 1867), and $E_{x}$ parte Garland, 4 Wall. 333 (U.S. 1867), as bad law. See, c.g., Green v. Shumway, 39 N.Y. 418, 433 (1868) (dissenting opinion).

For an extreme example of a Philippic against those who dare to challenge "patrictic" legislation as a bill of attainder, see Dworken v. Board of Education, 57 Ohio Law Abstract 449, 456-60, 94 N.E.2d 18, 22-25 (C.P. 1950).

10. Cummings v. Missouri, 4 Wall. 277, 323 (U.S. 1867). Also, see Ogden v. Saunders, 12 Wheat. 213, 266, 286 (U.S. 1S27) ; Calder v. Bull, 3 Dall. 3\&6, $3 \$ 9$ (U.S. 1798); Norris v. Doniphan, 4 IIetc. 385, 427 (Ky. 1863) ; People v. Hayes, 140 N.Y. 484, 490, 35 N.E. 951, 952 (1894) ; Pound, sispra note 1, at S-9.

11. United States v. Lovett, $32 S$ U.S. 303, 315 (1946).

12. E.g., 17 CAR II, c. 5 (1665); and statutes involved in Clarendon's Case, 6 How. St. Tr. 291 (1667) ; Cooper v. Telfair, 4 Dall. 14 (U.S. 1800); Thompson v. Carr, 5 N.H. 510 (1831) ; Respublica v. Gordon, 1 Dall. 232 (Pa. 1788).

13. E.g., 28 HeN. VIII, c. 18 (1536). 
discreet enough to name its victims specifically. ${ }^{14}$ Similarly, statutes describing the individuals to be punished, so that their identity is as obvious as if they had been named, have been rare. ${ }^{15}$

The overwhelming number of bills of attainder in the United States have selected their victims by means of expurgatory oath. ${ }^{10}$ The legislature requires an individual to forswear commission of specified acts before he is allowed to enjoy certain rights and privileges. ${ }^{17}$ An easily identifiable group, namely, those who cannot truthfully take the oath, are thereby deprived of those rights and privileges. In the companion Civil War cases of Cummings v. Missouri ${ }^{18}$ and Ex parte Garland, ${ }^{10}$ the United States Supreme Court, five to four, invalidated as bills of attainder legislative acts which singled out their victims by such expurgatory oaths. The majority pointed out that the constitutional prohibition would be a "vain and futile proceeding" if it could be avoided simply by replacing names or descriptions with some slightly less direct method of identification. ${ }^{20}$ This principle has never since been seriously challenged. ${ }^{21}$

However, statutes applying to specific individuals or groups, without more, are not bills of attainder. ${ }^{22}$

14. United States v. Lovett, 328 U.S. 303 (1946).

15. In re Yung Sing Hee, 36 Fed. 437 (C.C.D. Ore. 1888) ; Jones v. Slick, 56 So.2d 459 (Fla. 1952) ; Opinion to the House of Representatives, 96 A.2d 623 (R.I. 1953); McFarland v. American Sugar Refining, 241 U.S. 79, 85 (1916) semblc.

16. Out of 22 final decisions clearly holding that statutes violate the constitutional prohibition of bills of attainder, 16 involved expurgatory oaths.

The distinction between the ordinary oath of office and expurgatory oaths should be noted. "The original, and as yet the principal, object of official oaths is to require from the person about to enter upon the discharge of the duties of a public trust a gutaranty that he will be conscientious in the discharge of such duties and faithful to the public obligations he is about to assume." Commonwealth v. Jones, $73 \mathrm{Ky} .725,736$ (1874).

17. See, e.g., oaths in Cummings v. Missouri, 4 Wall. 277, 280-1 (U.S. 1867), and Ex parte Garland, 4 Wall. 333, 334-5 (U.S. 1867).

18. 4 Wall. 277 (U.S. 1867).

19. 4 Wall. 333 (U.S. 1867).

20. Cummings v. Missouri, 4 Wall. 277, 325 (U.S. 1867). Also, sce Matter of Dorsey, 7 Porter 293, 367 (Ala. 1838) (anti-dueling oath prerequisite to public office).

The Cummings minority could find no bill of attainder because a statute requiring an expurgatory oath "leaves the party himself to determine his own guilt or innocence, and pronounce his own sentence. It is not, then, the act of Congress, but the party interested, that tries and condemns." Ex parte Garland, 4 Wall. 333, 390 (U.S. 1867).

21. Five years later a majority of eight struck down an expurgatory oath in a onesentence memorandum opinion on the authority of Cummings and Garland. Picrec v. Carskadon, 16 Wall. 234 (U.S. 1872).

22. Presser v. Illinois, 116 U.S. 252, 268 (1886) (statute prohibited non-goverumental military organizations without permit); Dodez v. United States, 154 F.2d 637 (Gth Cir.), rev'd on other grounds sub nom. Gibson v. United States, 329 U.S. 338 (1946) (Selective Service Act) ; Perez v. Board of Police Commissioners, 78 Cal. App. 2d 638, 178 P.2d 537 (1947) (regulation prohibited union membership to policemen); People v. Camper- 


\section{What Constitutes Punisharent}

Historically, the term "bill of attainder" was restricted to those statutes which punished their victims by death or exile and corrupted their blood, so that they could not pass property by inheritance.23 When the sanction was less severe, as a deprivation of political rights, the act was labeled a bill of pains and penalties. ${ }^{24}$

It is not necessary that a statute "attaint" its victims for it to violate the constitutional prohibition of bills of attainder. Various early American bills of pains and penalties were defended against the charge of unconstitutionality on the ground that no attaint was involved. ${ }^{25}$ This argument was rejected by Cummings and Garland, which held that bills of pains and penalties were also proscribed and that deprivation of the right to pursue the occupations of priest and attorney constituted punishment. ${ }^{28}$

lingo, 69 Cal. App. 466, $231 \mathrm{Pac}, 601$ (1924) (illegal for convicted criminal to possess firearms) ; People v. Casa Co., 35 Cal. App. 194, 169 Pac. 454 (1917) (statute provided for abatement of bawdy houses) ; State ex rel. Wilcox v. Ryder, 120 MFinn. 95, 147 N.W. 953 (1914) (same) ; Detroit v. AASER \& MICE of A., 332 Mich. 237, 51 N.WV.2d 228, appeal dismissed, 344 U.S. 805 (1952) (statute prohibited public employees from strilsing) ; State v. Traffic Telephone Workers' Federation, 2 N.J. 335, 66 A.2d 616 (1949) (statute required compulsory arbitration of public utility labor disputes); Friedman v. American Surety Co., 137 Tex. 149, 151 S.W.2d 570 (1941) (statute rcquired empluyers to contribute to unemployment compensation fund) ; Christie v. Lueth, 265 Wis. 326, 61 N.W.2d 338 (1953) (city council passed resolution directing police chief to file charges against police officer and Police and Fire Commission to investigate the charges).

If every statute which applied to specific individuals or groups were a bill of attainder, it would be impossible to pass any criminal or regulatory legislation which applied to anything less than all persons within the jurisdiction.

Moreover, "[t]here is no vested right in individuals to have rules of law remain unchanged for their benefit." NLRB v. Edward G. Budd Mifg. Co., 169 F.2d 571, 579 (6th Cir. 1948), cert. denied sub nom. Foreman's Association of America v. Edward G. Budd MIfg. Co., 335 U.S. 908 (1949) (provision of Taft-Hartley Act removing supervisory employees from protection of Wagner Act held not bill of attainder).

23. Cummings v. Missouri, 4 Wall. 277, 323 (U.S. 185́7); 2 Story, Conserenrantes on tHe Constitution \$1344 (5th ed., Bigelow, 1891 ).

24. See note 23 supra.

25. This argument has found some judicial support. See, e.g., Ex parfe Hunter, 2 W. Va. 122, 184 (1867) (concurring opinion); Ex parte Garland, 4 Wall. 333, 387 (1867) (dissenting opinion).

26. Cummings v. Missouri, 4 Wall. 277, 320-2 (U.S. 1S67) (priest) ; Es parte Garland, 4 Wall. 333, 377 (U.S. 1867) (attorney) ; accord, Ex parte Law, 15 Fed. Cas. 3, No. 8,126, 35 Ga. 285 (S.D. Ga. 1866) (same); In re Baxter, 2 Fed. Cas. 1043, No. 1,118 (C.C.E.D. Tenn. 1866) (same); In $r c$ Shorter, 22 Fed. Cas. 16, No. 12,811 (D. Ala. 1865) (same) ; Matter of Dorsey, 7 Porter 294 (Ala. 1838) (same); State c.r rcl. Pittman v. Adams, 44 Mo. 570 (1869) (college trustee); State v. Heighland, 41 MIo. 385 (1867) (teacher) ; Murphy \& Glover Test Oath Cases, 41 Mo. 339 (1867) (preacher, attorney). Contra: Cohen v. Wright, 22 Cal. 293 (1863) (attorney); State v. Garecche, 36 Mo. 256 (1865) (same); Ex parte Quarrier and Fitzhugh, 4 W. Va. 210 (1870) (same) ; Ex parte Hunter, 2 W. Va. 122 (1867) (same). 


\section{Privilege v. Punishment}

Numerous state court decisions refused to find any punishment where the sanction imposed was loss of one of the "privileges" of citizenship. ${ }^{27}$ Cummings and Garland were distinguished on the ground that they had involved denial of one's right to earn his living in his chosen vocation. ${ }^{28}$ Efforts to use the privilege theory to deprive victims of the capacity to sue and to defend in the courts were halted by the United States Supreme Court in a onesentence memorandum opinion reversing a state court on the authority of Cummings and Garland..$^{29}$ But this was until recently the only bill of attainder case to bring the privilege theory before the high Court, ${ }^{30}$ and the absence of a full opinion made it easy to distinguish away. Consequently, the state courts, with the notable exception of the New York Court of Appeals, ${ }^{31}$ almost universally held that where the victim lost his vote or was denied public office there was no bill of attainder because loss of a "privilege" was not punishment. ${ }^{32}$ Recently, two state trial courts reached the same result with regard to receipt of unemployment compensation. ${ }^{33}$

Two United States Supreme Court decisions in the past decade reject the rationale that deprivation of a privilege cannot be punishment within the

27. See cases cited notes $32-3$ infra.

28. See, e.g., State v. Neal, 42 Mo. 119, 122-3 (1868) ; Blair v. Ridgely, 41 Mo. 63, $172-4$ (1867). Language supporting this view is found in In re Baxter, 2 Fed. Cas. 1043, 1044, No. 1,118 (C.C.E.D. Tenn. 1866) (same oath as Garland invalidated).

29. Pierce v. Carskadon, 16 Wall. 234 (U.S. 1872) ; accord, Lynch v. Hoffman, 7 W. Va. 553, 578 (1874); Ross v. Jenkins, 7 W. Va. 284 (1874); Kyle v. Jenkins, 6 W. Va. 371 (1873); cf. Davis v. Pierse, 7 Minn. 13 (1862). See also McNealy v. Gregory, 13 Fla. 417 (1870) (state constitutional provision abolishing all claims and judgments arising out of sales of slaves since 1861 'struck down). But cf. Drehman v. Stifle, 8 Wall. 595 (U.S. 1869) (state constitution provided act done under military authority of United States was absolute defense to civil action).

30. Had bill of attainder been argued, the issue would have been squarely put in Davis v. Beason, 133 U.S. 333 (1890), in which the Court upheld an anti-Mormon oath as a prerequisite to voting in Idaho.

31. Green v. Shumway, 39 N.Y. 418 (1868) (expurgatory Civil War oath prerequisite to vote) ; cf. Commonwealth v. Jones, $73 \mathrm{Ky} .725$ (1874) (anti-dueling oath prerequisite to public office). See also Matter of Dorsey, 7 Porter 294 (Ala. 1838) (same).

32. E.g., Shepherd v. Grimmett, 3 Idaho 403, 31 Pac. 793 (1892) (voting); Wooley v. Watkins, 2 Idaho 590, 22 Pac. 102 (1889) (same); Crampton v. O'Mara, 193 Ind. 551, 139 N.E. 360 (1923), appeal dismissed, 267 U.S. 575 (1925) (public office); Anderson v. Baker, 23 Md. 531 (1865) (voting); Blair v. Ridgely, 41 Mo. 63 (1867) (same); State ex rel. Wingate v. Woodson, 41 Mo. 227 (1867) (public office); Randolph v. Good, 3 W. Va. 551 (1869) (voting); cf. Boyd v. Mills, 53 Kan. 594, 37 Pac. 16 (1894) (same).

There are some areas where the legislature has unquestionable authority, as to expel its own members. French v. Senate, 146 Cal. 604, 80 Pac. 1031 (1905). Cf. Gray v. McLendon, $134 \mathrm{Ga}$. 224, 67 S.E. 859 (1910) (legislative removal of state railroad commissioner upheld).

33. State v. Hamilton, 92 Ohio App. 285, 110 N.E.2d 37 (1951); Dworken v. Collopy, 56 Ohio Law Abstract 513, 91 N.E.2d 564 (C.P. 1950). See also National Maritime Union v. Herzog, 78 F. Supp. 146 (D.D.C. 1948), aff'd per curiam on other grounds, 334 
definition of bills of attainder. ${ }^{34}$ In United States $v$. Lovett, ${ }^{35}$ the sanctuary of the privilege doctrine, government employment, collapsed. A rider on an appropriations bill prohibited payment of further compensation to three named federal employees. ${ }^{36}$ The Court interpreted this as a "permanent proscription from any opportunity to serve the Government [which] is punishment . . . of a most severe type."37 American Communications Association v. Douds ${ }^{\text {ss }}$ concerned a provision of the Taft-Hartley Act requiring union officials to execute a loyalty oath and a non-Communist affidavit. 30 If they failed to do so, their unions were denied access to the National Labor Relations Board.40 Though refusing to find a bill of attainder on other grounds, the Court granted that denial of access to the NLRB could constitute punishment.11

U.S. 854 (1948) (same statute as in American Communications Association v. Douds, 339 U.S. 382 (1950), see text at notes 55-6 infra).

The ultimate in reasoning is achieved in the Divorken case. "It is simply intended that persons disloyal to our government may not participate in its bounty. It is calculated to avoid the danger of having the hand that offers food, bitten by the recipient thercof." Dworken v. Collopy, 56 Ohio Law Abstract 513, 524, 91 N.E.2d 564, 572 (C.P. 1950).

34. This accords with the principle that the state cannot impose arbitrary and unconstitutional limitations on the exercise of a privilege. Sce Wieman v. Updegraff, 344 U.S. 183, 192 (1952) (government employment); United Public Worlss v. Mitchell, 330 U.S. 75, 100 (1947) (same).

35. 328 U.S. 303 (1946).

36. Emergency Appropriation Act of 1943, $\$ 304,57$ STAт. 450 (1943). A spacial House committee had conducted an investigation and concluded that Lovett, Watson, and Dodd were disloyal. H.R. REP. No. 448, 78th Cong., Ist Sess. (1943). The history of the bill is traced in the court opinion. United States v. Lovett, 32S U.S. 303, 30S-313 (1946). A more detailed account appears in Schuman, 'Bill of Attainder' In the Scanty-Isight' Congress, 37 Axr. PoL. Scr. Rev. 819 (1943).

It is not to be inferred that the Court considered the legislative history pertinent to the issue whether the rider fitted the definition of bill of attainder. Rather the majority used this information merely to determine whether Congress meant only to force Lovett, Dodd, and Watson to sue for their compensation, as the Court of Claims majority had held, Lovett v. United States, 104 Ct. Cl. 557, 584, 66 F. Supp. 142, 147-8 (1945), and Justices Frankfurter and Reed, concurring, agreed, United States v. Lovett, 328 U.S. 303, 330 (1946), or whether Congress intended to bar the three from federal employment, as the Supreme Court majority held, id. at 313-14.

37. Id. at 316. Cf. Bailey v. Richardson, 182 F.2d 46 (D.C. Cir. 1950), aff'd arithust opinion by an equally divided Court, 341 U.S. 918 (1951) (holding 3-ycar bar from Government service "punishment" which violates Sixth Amendment when imposed without judicial trial). See Wieman v. Updegraff, 344 U.S. 183, 190-1 (1952); Lovett v. United States, 104 Ct. C. 557, 587, 66 F. Supp. 142, 149 (1945) (concurring opinion). But see Detroit v. AASER \& MCE of A., 332 MFich. 237, 247, 51 N.W.2d 228, 232 (1952).

38. 339 U.S. 382 (1950).

39. $\$ 9(\mathrm{~h}), 61$ Stat. 146 (1947), 29 U.S.C. $\$ 159$ (h) (Supp. 1952).

40. Ibid.

41. American Communications Ass'n v. Douds, 339 U.S. 3\$2, 389-90 (1950).

Thus it seems clear that the denial of any right or privilege can be a sufficient deprivation to constitute punishment. This should have been obvious from Cummings. "The deprivation of any rights, civil or political, previously enjoyed, may be punishment. . . " Cummings v. Missouri, 4 Wall. 277, 320 (1867). And "rights" were defined brosdly 


\section{Qualification v. Punishment}

In its initial encounter with bills of attainder, the United States Supreme Court in Cummings distinguished punishment from failure to meet legitimate qualifications. The Court stated, "[Q]ualifications relate to the fitness or capacity of the party for a particular pursuit or profession."42 Under attack was a provision of the Missouri Constitution requiring almost everyone who desired to assume a position of any importance in public or private life to disavow a wide variety of acts ranging from active support of to sympathy with the Confederacy. ${ }^{43}$ The Court held that these deprivations constituted punishment. ${ }^{44}$

Attainable Qualifications and Avoidable Disqualifications. Dent v. West Virginia ${ }^{45}$ established the principle that a law setting up attainable qualifications, standards which everyone has at least a theoretical opportunity to meet, is not a bill of attainder. In that decision, the United States Supreme Court upheld a statute requiring physicians to obtain a license in order to practice. ${ }^{46}$ To qualify for a license, an applicant needed a diploma from a recognized medical school, ten years' experience in practice, or a passing

enough to include what other courts have called "privileges." "The theory upon which our political institutions rest is, that all men have certain inalienable rights-that among these are life, liberty and the pursuit of happiness; and that in the pursuit of happiness all avocations, all honors, all positions, are alike open to every one. . . ." Id. at 321.

Where nothing happens, there is, of course, no punishment and no bill of attainder. Dworken v. Board of Education, 57 Ohio Law Abstract 449, 94 N.E.2d 18 (C.P. 1950), aff'd, 63 Ohio Law Abstract 10, 108 N.E.2d 103 (Ct. App.), appeal dismissed, 156 Ohio St. 346, 102 N.E.2d 253 (1951) (loyalty oath for teachers, but no implementation).

Likewise, where a matter is merely preliminary to an adjudication, there is no punishment. In re De Giacomo, 7 Fed. Cas. 366, No. 3,747 (C.C.S.D.N.Y. 1874) (extradition); Mosher v. Bay Circuit Judge, 108 Mich. 503, 66 N.W. 384 (1896) (statute authorized commencement of suit by attachment before maturity of debt); Christie v. Lueth, $265 \mathrm{Wis.}$ 326, 61 N.W.2d 338 (1953) (city council passed resolution directing police chief to file charges against a police officer and Police and Fire Commission to investigate the charges).

42. Cummings v. Missouri, 4 Wall. 277, 319 (U.S. 1867).

43. Id. at 279-81.

44. Id. at 320 . In dictum, the majority gratuitously observed that many (but not all) of the acts which Cummings was required to deny bore "no possible relation to [his] fitness" for the priesthood. Id. at 319. However, the Court did not rest its decision on relevancy. The oath "was required in order to reach the person, not the calling. It was exacted not from any notion that the several acts designated indicated unfitness for the callings, but because it was thought that the several acts deserved punishment. . . ." Id. at 320. And in the companion case of Ex parte Garland, 4 Wall. 333 (U.S. 1867), the Court stated, "The question . . . is not to the power of Congress to prescribe qualifications [for attorneys], but whether that power has been exercised as a means for the infliction of punishment. ..." Id. at 379-80.

It could scarcely be contended that Congress could not reasonably decide that past loyalty to the Union was relevant to the qualifications of an officer of the federal courts. Cf. In re Summers, 325 U.S. 561 (1945).

45. 129 U.S. 1.14 (1889).

46. Dent v. West Virginia, 129 U.S. 114 (1889). 
score on a special examination. ${ }^{47}$ On the attainable qualifications rationale, courts have always upheld, against the charge of bill of attainder, statutes setting standards of education and of skill for various occupations ${ }^{\text {ts }}$ or requiring payment of fees. ${ }^{49}$

In the Lo'vett case, Justice Frankfurter, concurring, sketched out a theory that a prospective statute could not be a bill of attainder because it did not "punish" past conduct. ${ }^{50}$ This followed from his requirements that, to be a bill of attainder, a statute must specify the offense and contain a declaration of guilt.51 Obviously, a prospective statute can contain neither. Moreover, Justice Frankfurter was willing to admit that such formal requisites could easily be evaded as to past acts.22 This view diametrically opposes that of the Court in Cummings: "If the inhibition [on bills of attainder] can be evaded by the form of the enactment, its insertion in the fundamental law was a vain and futile proceeding." 53

Nevertheless, in the Douds case, ${ }^{\text {, }}$ the majority of the Supreme Court adopted the view that a prospective statute could not be a bill of attainder. Sec-

47. Id. at $115-1 \%$.

48. Reetz v. Michigan, 1SS U.S. 505 (1903) (board to examine qualifieations of, and to license, physicians); Butcher v. Maybury, \& F.2d 155 (W.D. Wash. 1925) (educatiunal requirements for drugless healers) ; France v. State, 57 Ohio St. 1, 47 R.E. 1041 (1897) (same as Dent) ; Davis v. Beeler, 185 Tenn. 638, 207 S.W.2d 343 (1947), appeal dismissed, 333 U.S. 859 (1948) (stiffer qualifications for naturopaths) ; of. Davis v. Savannah, $147 \mathrm{Ga}$. 605, 95 S.E. 6 (191S) (sanitary regulation of milk production).

49. In re Platz, 60 Niev. 296, 108 P.2d 858 (1940) (attorneys required to pay bar association dues); Kelly v. State Bar of Ollahoma, 148 Olila. 2\$2, 298 Pac. 623 (1931) (same) ; cf. Jones v. Ellis, 182 Ga. 380, 185 S.E. 510 (1936) (inerease in bond rcquired of school district secretary-treasurer); Losier v. Sherman, 157 Kan. 153, 138 P.2d 272 (1943) (statute specified conditions on which judgment creditor could garnish debtor's earnings).

50. See United States v. Lovett, 328 U.S. 303, 323 (1946) (concurring opinion). Justice Frankfurter reasoned that a statute could not be a bill of attainder unless it was also an ex post facto law. Ibid. This ignores the full implieations of the requirement of a judicial trial for a statute to avoid constituting a bill of attainder. See pages $857-61$ infra.

51. United States v. Lovett, 328 U.S. 303, 322-3 (1946).

52. "Congress need merely omit its ground of condemnation and legislate the penalty! But," Justice Frankfurter added, "the prohibition against a "Bill of Attainder' is only" one of the safeguards of liberty in the arsenal of the Constitution. There are other provisions in the Constitution, specific and comprehensive, effectively designed to assure the liberties of our citizens." Id. at 326. Cf. Wolf v. Colorado, 338 U.S. 25, 31-2 (1949). These "other provisions" can be none other than the due process and judicial rights amendments of the Constitution. Hence, Justice Frankfurter would permit what were intended as additional safeguards to operate in derogation of the bill of attainder prohibitions of the original document. Moreover, the protection of the judicial rights amendments comes into play only once one gets inside the judicial arena. Sce text at notes 124-5 infra.

53. Cummings v. Missouri, 4 Wall. 277, 325 (U.S. 1867).

54. American Communications Ass'n v. Douds, 339 U.S. 382 (1950) (5-1 decision). Cf. Gerende v. Board of Supervisors, 341 U.S. 56 (1951) (loyalty osth required of candidates for public office in Maryland upheld without mention of bill of attainder). 
tion 9(h) of the Taft-Hartley Act requires union officers to execute a nonCommunist affidavit and loyalty oath in order that their unions may have access to the NLRB. ${ }^{55}$ The oath inquires only into present membership and loyalty. ${ }^{56}$ Chief Justice Vinson, writing for the majority in upholding the statute, distinguished this oath from those concerning past conduct which had been invalidated in Cummings and Garland. ${ }^{57}$ Moreover, he was unable to discern how there could be punishment when the impact of the statute could be avoided "by a voluntary alteration of loyalties" (and membership). ${ }^{\text {to }}$ The majority found a legitimate public interest in the prevention of political strikes in interstate commerce. ${ }^{59}$ They could see nothing wrong with the expurgatory oath as a device for determining which union leaders would be most likely to call such strikes. ${ }^{60}$

55. 61 StaT. 146 (1947), 29 U.S.C. $\$ 159$ (h) (Supp. 1952).

56. Ibid.

57. American Communications Ass'n v. Douds, 339 U.S. 382, 413 (1950); accord, Albertson v. Millard, 106 F. Supp. 635 (E.D. Mich. 1952), vacated and remanded, 345 U.S. 242 (1953) (Michigan's Trucks Act, inter alia, banned Communist Party from ballot); Shub v. Simpson, 196 Md. 177, 76 A.2d 332, appeal dismissed as moot, 340 U.S. 881 (1950) (non-subversive affidavit prerequisite to candidacy for public office); Huntamer v. Coe, 40 Wash. 2d 767, 246 P.2d 489 (1952) (same); Thorp v. Board of Trustces, 6 N.J. 498, 79 A.2d 462 (1951) (loyalty oath for teachers).

Support for this view is found in dicta in the seriatim majority and minority opinions of Ogden v. Saunders, 12-Wheat. 213, 266, 303, 329, 336 (U.S. 1827).

58. American Communications Ass'n v. Douds, 339 U.S. 382, 414 (1950). This seems to be diametrically opposed to the following language from Cummings: "These bills may inflict punishment absolutely, or may inflict it conditionally." Cummings v. Missouri, 4 Wall. 277, 324 (U.S. 1867). The reference was to one type of parliamentary bill of attainder which imposed punishment on those members of a described group who failed to surrender themselves by a given date to stand trial. E.g., Clarendon's Case, 6 How. St. Tr. 291 (1667). On the basis of this historical background, an old Kentucky decision invalidated a prospective statute providing for forfeiture of lands for failure to occupy and to cultivate them. Doe $e x$ dem. Gaines v. Buford, 1 Dana 481 (Ky, 1833).

Moreover, the mere fact that a statute is prospective does not mean that it is avoidable. Opinion to the House of Representatives, 96 A.2d 623 (R.I. 1953), struck down as a bill of attainder a statute disqualifying relatives of city officials from holding appointive city offices. See also Jones v. Slick, 56 So.2d 459 (Fla. 1952), holding a city ordinance providing for the fine and/or imprisonment of local officials upon conviction for offenses by a two-thirds vote of the city council to be a bill of attainder.

59. American Communications Ass'n v. Douds, 339 U.S. 382, 390-1 (1950). Also, see Inland Steel Co. v. NLRB, 170 F.2d 247, 267 (7th Cir. 1949) (same statutory provision).

60. American Communications Ass'n v. Douds, 339 U.S. 382, 408-09 (1950). The resemblance to the defense given by the Garland dissenters should be noted. "The history of the time when this statute was passed-the darkest hour of our great struggle-the necessity for its existence, the humane character of the President who signed the bill, and the face of the law itself, all show that it was purely a qualification', exacted in selfdefense, of all who took part in administering the government in any of its departments, and that it was not passed for the purpose of inflicting punishment, however merited, for past offenses." Ex parte Garland, 4 Wall. 333, 396 (U.S. 1867). 
The deprivation in Douds stemmed not from a failure to meet an "attainable qualification" but from a failure to avoid an "avoidable disqualification." In cases like Dent, ${ }^{61}$ an individual qualifies by adding something to his existing attributes: by obtaining a diploma from a recognized medical school, by passing an examination, by paying a fee. ${ }^{62}$ Under section $9(\mathrm{~h})$ of the TaftHartley Act, ${ }^{63}$ an easily ascertainable group determined by expurgatory oath, namely, Communist union officials, must surrender their posts if their unions are to have access to the NLRB. But this disqualification can be escaped if they will only recant and renounce their affiliation with the Communist Party. ${ }^{64}$ Thus they can "qualify," not by adding to, but by divesting themselves of one of, their existing attributes.

Unavoidable Disqualifications Based on Past Acts. Just as some courts tended to uphold any prospective statute on the theory that it merely established "qualifications," 65 so other courts baldly stated that any retrospective statute imposed "disqualifications," which made it a bill of attainder. the criteria were based on past conduct, some existing persons would find it impossible to qualify. ${ }^{67}$ These individuals were said to be conclusively "disqualified." 68 The statute imposed "punishment" on them and was therefore a bill of attainder..$^{69}$

The theory that a statute imposing unavoidable disqualifications was necessarily a bill of attainder collapsed with Hawker $v$. Ncw York..$^{0}$ In that case, the United States Supreme Court upheld, six to three, a statute disqualifying convicted felons from the practice of medicine, as applied to an abortionist convicted prior to the passage of the statute. ${ }^{71}$ The Court reasoned that a state might rightfully require good character of those who would practice medicine and that it could reasonably determine that conviction of a felony was conclusive evidence of bad character. ${ }^{\text {i2 }}$ A vigorous dissent, accepting the qualification-disqualification dichotomy, rested on the ground that Hawker could not undo the past act and qualify. ${ }^{73}$

61. Dent v. West Virginia, 129 U.S. 114 (1SS9), discussed in text at notes $45-7$ supra.

62. See cases cited in notes 48 and 49 supra.

63. See text at notes 55-6 supra.

64. See text at note 58 supra.

65. American Communications Ass'n v. Douds, 339 U.S. 382 (1950); Matter of Dorsey, 7 Porter 294, 359 (Ala. 1838).

66. Matter of Dorsey, 7 Porter 294, 359 (Ala. 1838). See Hawker v. New Yorl:, 170 U.S. 189, 203-04 (1898) (dissenting opinion). Language in Cummings appars to support this view. "Any deprivation or suspension of any of these rights for past conduct is punishment, and can be in no otherwise defined." Cummings v. Mfissouri, 4 Wall. 277, 322 (U.S. 1S67).

67. See note 66 supra.

68. Ibid.

69. Ibid.

70. 170 U.S. 189 (1898).

71. Hawker v. New York, 170 U.S. 189, 189-90 (1898).

72. Id. at 196.

73. Id. at 200-05. 
Since Hawker did not overrule Cummings and Garland, its distinguishing features are significant. The statutes invalidated by Cummings and Garland operated on existing individuals who, because of past acts, could not truthfully take an expurgatory oath. ${ }^{74}$ By contrast, the statute upheld in Hawkor applied to all those who had been and would in the future be convicted of felonies by courts. ${ }^{75}$ Past acts as such were irrelevant; significance was attached only to judicial convictions. ${ }^{76}$

An expurgatory oath retrospective on its face came before the Supreme Court in Garner v. Board of Public Works. ${ }^{77}$ In 1941 the California legislature amended the City Charter of Los Angeles to bar from city offices and jobs persons who advocated subversive views or were associated with stbversive organizations. ${ }^{78}$ Pursuant to the amendment, Los Angeles in 1948 passed an ordinance requiring all city employees to make oath that they had not advocated subversive views or been associated with any subversive organization since 1943, five years prior to enactment of the ordinance. ${ }^{70}$

A five-judge majority upheid the oath in spite of its retrospective features by relating it back to the charter amendment. ${ }^{80}$ "The activity covered by the

74. Cummings v. Missouri, 4 Wall. 277, 325 (1867) ; Ex parte Garland, 4 Wall. 333, 377 (1867).

75. See note 71 supra and accompanying text.

76. "[If the legislature] may make a violation of criminal law a test of bad character, what more conclusive evidence of the fact of such violation can there be than a conviction duly had in one of the courts of the state? The conviction is, as between the state and the defendant, an adjudication of fact." Hawker v. New York, 170 U.S. 189, 196 (1898).

77. 341 U.S. 716 (1951).

78. Garner v. Board of Public Works, 341 U.S. 716, 717-18 (1951). The Charter amendment itself punported to bar those who had engaged in the proscribed conduct for the five previous years as well. Ibid. The Court assumed, however, that the amendment would be applied only to conduct subsequent to its adoption. Id. at 720 .

79. Id. at 718-19. The ordinance also required employees to file an affidavit as to membership in the Communist Party. Id. at 719. The affidavit was upheld, seven to two, on the ground that it was merely for informational purposes. Id. at 720, 725-6, 730. Justice Douglas, dissenting, considered the affidavit merely a mechanism in enforcing the ordinance, which he considered a bill of attainder. Id. at 732 .

80. Garner v. Board of Public Works, 341 U.S. 716 (1951) ; accord, Hirschman v. Los Angeles County, 231 P.2d 140 (Cal. App. 1951), aff'd on other grounds, 39 Cal. 2d 698, 249 P.2d 287 (1952) (same oath and affidavit but for county instead of city) ; cf. Board of Regents v. Updegraff, 205 Okla. 301, 237 P.2d 131 (1951), rev'd sub nom. Wieman v. Updegraff, 344 U.S. 183 (1952).

In Garner, Justice Burton, dissenting, refused to accept the majority's relation back doctrine. 341 U.S. 716, 729 (1951). Justice Douglas, dissenting, stressed the fact that the oath inquired into past conduct, $i d$. at $735-6$, but did not rest on this ground. $1 d$. at $733-6$.

The use of precedent by the Garner majority is, to say the least, interesting. Except for Gerende v. Board of Supervisors, 341 U.S. 56 (1951), none of the cases cited as support involved oaths; and Gerende, a one-paragraph per curiam opinion, did not even mention bills of attainder. Therefore the Court must have been relying sub silentio on American Communications Ass'n v. Douds, 339 U.S. 382 (1950). But both Gerchic and Douds involved "avoidable disqualifications," see text at notes $61-4$ supra; the city ordi- 
oath had been proscribed by the Charter in the same terms, for the same purpose, and to the same effect over seven years before, and two years prior to the period embraced in the oath."\$1 The majority refused to find a bill of attainder, holding that the charter and ordinance merely "declare general and prospectively operative standards of qualification and eligibility for public employment." ${ }^{\prime 2}$ Apparently to mitigate the retrospective aspects of the outh. however, the Court injected scicnter. ${ }^{83} A$ city employee could not be fired unless he knew' (whether or not he agreed with) the objectives of subversive organizations he joined. ${ }^{84}$

The Present State of the Law. Since Lozitt, ${ }^{85}$ the Lnited States Supreme Court has consistently narrowed the scope of the bill of attainder prohibition. In Douds, ${ }^{86}$ the Court upheld a statute requiring an e:spurgatory oath with regard to present conduct. This was approved because no one was conclusive$1 y$ disqualified on the basis of past conduct. ${ }^{87}$ Whatever disqualification there was could be avoided "by a voluntary alteration of loyalties." the Court upheld an ordinance requiring an expurgatory oath concerning conduct prior to the oath. ${ }^{30}$ Here there was no possibility of avoidance and past acts did disqualify an individual. ${ }^{91}$ Nonetheless, the majority approved this oath because a prior legislative act had prohibited the same conduct into which the oath inquired on the part of the same people who were required to talie the oath. ${ }^{92}$ The oath was considered a mere mechanism for imposing the "general and prospectively operative standards of qualification" established by the earlier statute. ${ }^{93}$

The Supreme Court has imposed some limitations on disqualifications based on past conduct because of other constitutional provisions. In Garner, the

nance in Garner reached back five years into the past. The wnly cast cited in support involving past acts was Hawker v. Xew York, 170 U.S. 189 (1598), and IIas/:er rested not on past acts elicited by oath but on judicial conviction of a feluny, sce nute 76 supra.

S1. Garner v. Board of Public Works, 341 U.S. 716, 721 (1951).

82. Id. at 723 .

83. Id. at 723-4. See also Wieman v. Cpdegraff, 344 C.S. 183 (1952); Gerende v. Board of Supervisors, 341 U.S. 56 (1951).

There vas no mention of scienter as to presull membership in American Cummunications Ass'n v. Douds, 339 U.S. 382 (1950). Thus, apparently, sisuler is required only as to past membership. But cf. Geronde, supra.

S4. Garner v. Board of Public Works, 311 U.S. 716, 723-4 (1951).

85. United States v. Lovett, $32 S$ U.S. 303 (1946).

86. American Communications Ass'n v. Douds, 339 U.S. 382 (1950).

87. Id. at 413.

88. Id. at 414 .

S9. Garner v. Board of Public Works, 341 U.S. 716 ( 1951 ).

90. See text at note 79 simpra.

91. The scicnter limitation imposed by the Court, see text at notes $83-4$ supro, does not make this any less so. See also note $126 \mathrm{infra.}$

92. See text at notes 78 and 81 supra.

93. Garner v. Board of Public Worls, 341 U.S. 716, 721, 723 (1951). 
Court did require scienter on the part of the oath-taker, but on the rationale that the Due Process Clause required it. ${ }^{94}$ In Wieman v. Updegraff, ${ }^{05}$ the Court invalidated on due process grounds an almost exact duplicate of the Garner oath, which also reached back five years into the past ;00 here the court was foreclosed from reading scienter into the oath..$^{27}$ Bill of attainder was argued but is not even mentioned in the Court opinion.98 And in Wieman there was no previous legislation to which the oath could be related back."0

IVieman left unanswered the question whether the present Supreme Court would hold that an oath inquiring into past conduct not previously forbidden to the same class of people by prior legislation violates the bill of attainder prohibition. In such a case, there would be no factual grounds left on which to distinguish Cummings and Garland as the Court has done thus far.

However, the present Supreme Court appears ready to permit its expanding qualification doctrine to swallow up Cummings and Garland completely. Under the Douds-Garner rationale, the only real question for bill of attainder purposes is whether, under the circumstances, the legislature could reasonably find the conduct inquired into relevant to the deprivations imposed. ${ }^{100}$ The Court appears to consider the mode of inquiry irrelevant. ${ }^{101}$ If the conduct itself is relevant, the Court reasons, the statute establishes qualifications instead of imposing punishment. ${ }^{102}$ Since the question of relevancy is primarily legislative, something the Cummings-Garland majority conceded, ${ }^{103}$ only the

94. Id. at 723-4 (1951).

95. 344 U.S. 183 (1952).

96. Wieman v. Updegraff, 344 U.S. 183, 184-5 (1952). The oath applied to all officers and employees of the State of Oklahoma.

97. Id. at 191.

98. Id. at 185 .

99. See id. at 184-5. Moreover, in its discussion of Garner, id. at 189-90, the Wicman opinion makes no mention of the prior charter amendment.

100. See text at notes 59-60, 82 supra. And, of course, past conduct is relevaut. "Past conduct may well relate to present fitness; past loyalty may have a reasonable relationship to present and future trust. Both are commonly inquired into in determining fitness for both high and low positions in private industry and are not less relevant in public employment." Garner v. Board of Public Works, 341. U.S. 716, 720 (1951).

101. In neither American Communications Ass'n v. Douds, 339 U.S. 382 (1950) nor Garner v. Board of Public Works, 341 U.S. 716 (1951) does the Court so much as intimate that the use of an expurgatory oath might have something to do with whether a statute is a bill of attainder. The only discussion of oaths as such is with regard to religious test oaths and oaths of office. American Communications Ass'n v. Douds, 339) U.S. 382, 414-15 (1950). Yet the expurgatory oath question was the basic issue in Cummings and Garland. Compare the majority in Cummings v. Missouri, 4 Wall. 277, 324-5 (U.S. 1867), with the dissent in Ex parte Garland, 4 Wall. 333, 389-90 (U.S. 1867).

102. Garner v. Board of Public Works, 341 U.S. 716, 722-3 (1951).

103. "The legislature may undoubtedly prescribe qualifications for the office, to which he must conform, as it may, where it has exclusive jurisdiction, prescribe qualifications for the pursuit of any of the ordinary avocations of life." Ex parte Garland, 4 Wall. 333, 379 (U.S. 1867). 
aberrational statute specifically naming its victims would be struck down under this standard..$^{104}$

\section{The Forgotten Element: Lack of Judicial Trint}

A bill of attainder is a legislative act which imposes punishment on named individuals or an easily ascertainable group without judicial trial. 105 The legislative acts involved in Cummings and Garland were invalid not simply because they imposed punishment, something every criminal statute does, but because they imposed punishment on an easily ascertainable group without judicial trial. ${ }^{108}$

There is no need for trial by courts when the concern is with statutes establishing strictly attainable qualifications or character standards. Practicability probably requires relegation of such matters to administrative boards. Courts will traditionally interfere when such boards exceed their powers. ${ }^{107}$ Thus the legislature can require loyalty of government employees without creating a bill of attainder so long as it does not itself single out, by oath or otherwise, some individuals or an identifiable group as conclusively disloyal. ${ }^{103}$

104. See discussion of the Loz'tt case in Garner v. Board of Public Worts, 341 L.S. 716, 723 (1951).

105. United States v. Lovett, $32 S$ U.S. 303, 315 (1946).

106. Cummings v. Missouri, 4 Wall. 277, 325 (U.S. 1867); Ex parte Garland, 4 Wall. 333,377 (U.S. 1867).

107. See, generally, Davis, Administrative Law c. 19 (1951). For a complete discussion of the extent of judicial review of refusal of the Bar to admit an attorney to practice, see Brooks v. Laws, 208 F.2d 1S (D.C. Cir. 1953).

108. The procedure followed by New York in its Feinberg Law illustrates the matter further. Subversives are barred from the teaching profession, and membership in a group listed by the State Board of Regents as subversive is prima faic eridence of individual subversiveness.

In Thompson v. Wallin, the Communist Party alleged that it was being punished by a bill of attainder. The trial court accepted this argument hecause the preamile to the statute mentioned the Communist Party by name. 196 Misc. 696, 696-7, 93 X.I.S.21 274, 283-4 (Sup. Ct. 1949). To this the Court of Appeals responded, "Such preamble enacts nothing, contains no directives and . . . is not made a part of the Edueation Law." 301 N.Y. 476, 493, 95 N.E.2d 806, 814 (1950). The Court of Apseals held that there was no bill of attainder because an organization threatened with listing is entitled to an administrative hearing with judicial review. 301 N.Y. 493, 95 N.E.2d at \$14, aspal dismissed, 342 U.S. 801 (1951).

Various teachers also sought to enjoin enforcement of the statute. The courts held no bili of attainder, pointing out that the individual was also entitled to an administrative hearing with judicial review. Membership in a subversive organization was not conclusive but only prima facie evidence for disqualifying a teacher as subversive. Under such a proceeding, punishment is based on individual "guilt" determined on a case to case basis with due regard to the requirements of due process. Lederman v. Board of Edueation, 276 App. Div. 527, 96 N.Y.S.2d 466 (2d Dep't), aff'd, 301 N.Y. 476, 95 N.E.2d 806 (1950), aff'd sub nom. Adler v. Board of Education, 342 U.S. 485 (1952); L'Hemmedieu v. Board of Regents, 276 App. Div, 494, 95 N.Y.S.2d 443 (3d Dep't), aff'd, 301 N.Y. 476, 95 N.E.2d 806 (1950). Cf. Weinstock v. Ladisky, 197 Misc. 859, 98 N.Y.S.2d 85 (Sup. 
Hawker, ${ }^{109}$ the only United States Supreme Court decision prior to Douds to permit direct legislative imposition of punishment upon an easily ascertainable group, rested disqualification on a past judicial conviction. The statute in Hawker prohibited convicted felons from practicing medicine; 110 in that case it was applied to an abortionist convicted prior to the passage of the law. ${ }^{111}$ Undeniably felons convicted prior to the passage of the law represented an easily identifiable group. However, the statute relied not on any past act as such, but on a judicial conviction of a crime serious enough to support a conclusive presumption that one convicted thereof lacked good character at a later date. ${ }^{112}$

This distinction based on the presence or absence of a judicial finding of guilt is clearly illustrated by several state court decisions in the post-Civil War period involving denial of the vote to deserters. Conviction of desertion resulted in loss of citizenship ; ${ }^{113}$ most states extended the vote only to United States citizens. ${ }^{114}$ Various convicted deserters urged that such franchise statutes operated as bills of attainder towards them. The courts made short shrift of this argument, pointing out the judicial conviction..$^{115}$ Kentucky, by con-

Ct. 1950) (amendment to union constitution banning subversives and fascists upon hearing held not bill of attainder).

109. Hawker v. New York. 170 U.S. 189 (1898).

110. Id. at 190.

111. Id. at $189-90$.

112. "[I]f the legislature enacts that one who has been convicted of crime shall no longer engage in the practice of medicine, it is simply applying the doctrine of res judicata and invoking the conclusive adjudication of the fact that the man has violated the criminal law, and is presumptively, therefore, a man of such bad character as to render it unsafe to trust the lives and health of citizens to his care." Id. at 196.

113. Huber v. Reily, $53 \mathrm{~Pa} .112,113$ (1866).

114. Ibid.

115. Gotcheus v. Matheson, 58 Barb. 152 (N.Y. Sup. Ct. 1870), rev'd on other grounds, 61 N.Y. 420 (1875) ; Huber v. Reily, 53 Pa. 112 (1866) ; cf. Story v. Rives, 68 App. D.C. 325,97 F.2d 182, cert. denied, 305 U.S. 595 (1938) (statute provided parole violators required to serve remainder of original sentence); Peer v. Skeen, 108 F. Supp. 921 (N.D.W.Va. 1952) (habitual criminal statute); Washington v. State, 75 Ala. 582 (1884) (illegal for those convicted of various crimes to vote); People v. Isracl, 91 Cal. App. 2d 773, 206 P.2d 62 (1949) (habitual criminal statute); People v. Lawrence, 390 IIl. 499, 61 N.E.2d 361 (1945) (same); Crampton v. O'Mara, 193 Ind. 551, 139 N.E. 360 (1923), appeal dismissed, 267 U.S. 575 (1925) (those convicted of infamous crimes dis* qualified from public office); State v. Graves. 352 Mo. 1102, 182 S.W.2d 46 (1944) (statute permitted impeachment of witness by prior conviction); Skinner v. State $c x r c l$. Williamson, 189 Okla. 235, 115 P.2d 123 (1941), rev'd on other grounds, 316 U.S. 535 (1942) (habitual criminal sterilization act); Estate of King, 261 Wis. 266, 52 N.W.2d 885 (1952) (murderer cannot take as surviving joint tenant). But cf. Davis v. Berry, 216 Fed. 413 (S.D. Iowa 1914), rev'd on other grounds, 242 U.S. 468 (1917) (habitual criminal statute providing for vasectomy). See also United States v. Distillery, 25 Fed. Cas. 866, No. 14,965 (D. Del. 1870) (statute provided for forfeiture of premises on which alcohol manufactured without payment of taxes); Department of Social Welfare v. Gardiner, 94 Cal. App. 2d 431, 210 P.2d 855 (1.949) (state could recover double against estate of deceased recipient of old age pension who failed to reveal property or income 
trast, required a prospective voter to swear that he had not deserted to the Confederacy as a prerequisite to exercise of his franchise. ${ }^{110}$ The court labeled the oath process a "mock-trial" and held the statute a bill of attainder. ${ }^{117}$

The judicial trial demanded by the bill of attainder prohibition must come before punishment is imposed. There are circumstances where a bill of attainder results in a different kind of judicial trial which does not satisfy the constitutional provision. Cummings was one such case; Cummings was tried for preaching without having taken the required expurgatory oath.118 And an individual may be prosecuted for falsely taking the oath. ${ }^{110}$ The issue in such cases is whether the defendant has attempted to escape the punishment imposed by the bill of attainder. Such a trial simply determines whether an individual is a member of the easily ascertainable group which the legislature has already punished without judicial trial. ${ }^{120}$ The punishment in such cases is wholly apart from the deprivations imposed by the legislature in the bill of attainder itself.

Douds ${ }^{121}$ and Garner ${ }^{122}$ subvert the American judicial process by substituting an inquisitorial for an accusatorial system of justice. The outh-talier is barred from the exercise of various rights and privileges whenever he is

in excess of statutory limit); Moore v. Commonwealth, $293 \mathrm{Ky.} \mathrm{55,} 168$ S.IV.2d 342 (1943) (statute provided for forfeiture of property used for sale of intoxicating liquors in dry territory); Moffett v. Commerce Trust Co., 354 Mo. 1098, 193 S.W.2d 598, appcal disnissed, 329 U.S. 669 (1946) (statute provided for dismissal with treble costs when three petitions found insufficient) ; State v. Coubal, 248 Wis. 247, 21 N.W.2d 381 (1946) (statute provided for issuance of injunctions prohibiting operation of gambling devices).

116. Burkett v. McCarty, $73 \mathrm{Ky} .758,759$ (1866).

117. "[T] $]$ he legislature may rightfully forfeit a citizen"s right to rote as a nanalty for perjury or other crime. But if a citizen be challenged at the polls as disqualified by crime, can he be excluded without or before conviction, and who can cunvict? [His commission of a crime] is necessarily a judicial question, which can be constitutionslly decided [only] by the judiciary on a full and fair trial on an indictment or a prescntment." Id. at 762.

118. Cummings v. Missouri, 4 Wall. 277, 316 (U.S. 1867).

119. Section $9(\mathrm{~h})$ of the Taft-Hartley Act, note $\$ 5$ safro, involved in American Communications Ass'n v. Douds, 328 U.S. 303 (1946), expressly su provides.

120. Of course, many pieces of criminal and regulatory legislation apply to an identifiable group, so that the only issue in a trial for violation thereof is in efiect whether a person belongs to the group. See note 22 supro. To call such a statute a bill of attainder would incorporate discredited notions of substantive due process. However, in the unlikely event that the legislature passed a statute providing that $X, Y$, and $Z$ were barred from government employment upon a judicial finding that they were $X, Y$, and $Z, a$ court might well call this a "mock-trial" and therefore a bill of attainder. See test at note 117 supra. The question in such a case would more properly be one of violation of the Equal Protection and Due Process Clauses by creating an unreasonable classification. See Skinner v. Oklahoma ex rol. Williamson, 316 U.S. 535 (1942).

121. American Communications Ass'n v. Douds, 328 U.S. 303 (1916); see notes 54-60 sispra and accompanying text.

122. Garner v. Board of Public Works, 341 U.S. 716 (1951); see notes 77-84 styro and accompanying text. 
unable to take the required oath truthfully. ${ }^{123}$ There is no grand jury indictment, no burden of proof on the state, no privilege against self-incrimination, no requirement of two witnesses to treasonable acts, no conviction by a petit jury of one's peers. ${ }^{124}$ There is no opportunity for a case by case determination of the existence of a "clear and present danger" when the proscribed conduct includes speech and political associations. ${ }^{125}$ Moreover, direct imposition of deprivations by the legislature admits no defense of lack of intent, coercion, self-defense, insanity, or anything else. ${ }^{126}$ And in the borderline case, the victim must decide an issue that should be determined by a court or by an administrative body. ${ }^{127}$

When the question is posed in these terms, the Garner theory that a prior prohibitory statute will validate a subsequent oath inquiring into violations of that statute ${ }^{128}$ stands exposed as the fallacy it is. Otherwise, criminal law administration could be greatly simplified by the enactment of a statute requiring everyone to make oath periodically that he had not committed various crimes and summarily visiting the usual punishments on those who could not truthfully take the oath.

The evils of bills of attainder lie not so much in what is done as in how it is done, in the usurpation of the judging function by the legislature. ${ }^{120}$ It was this separation of the proscribing and guilt-determining functions, accord-

123. Ex parte Garland, 4 Wall. 333, 377 (U.S. 1867).

124. See Cummings v. Missouri, 4 Wall. 277, 323 (U.S. 1867) ; In re Shorter, 22 Fed. Cas. 16, 19, No. 12,81.1 (D. Ala. 1865). This would seem to dispose of Justice Frankfurter's contention in Lovett, see note 52 supra, that the bill of attainder prohibition is a mere superfluity since other constitutional provisions offer adequtate protection.

125. Compare Dennis v. United States, 341 U.S. 494, 510 (1951), quoting Judge Learned Hand, " $[I] n$ each case [courts] must ask whether the gravity of the 'cvil,' discounted by its improbability, justifies such invasion of free speech as is necessary to avoid the danger," (emphasis added) with American Communications Ass'n v. Douds, 339 U.S. 382 (1950), which upheld the validity of the Taft-Hartley expurgatory onth once and for all. Since Douds, the only trial an individual can get on the oath is one for perjury in taking it. And in such a case, the First Amendment is irrelevant.

126. See Doe ex dem. Gaines v. Buford, 1 Dana 481, 492 (Ky. 1833). Disqualification on the basis of commission of an act instead of a judicial conviction tunder the statute in Hawker v. New York, 170 U.S. 189 (1898), would affect the physician who performed an abortion at gunpoint, a circumstance where acquittal would be foreordained in the judicial process. The attempted sop of scienter offered by Garner v. Board of Public Works, 341 U.S. 716, 723-4 (1951), text at note 84 supra, scarcely improves the situation. Obviously, the physician would know he had committed an abortion.

127. Where the statute involves an expurgatory oath, the victim faces the prospect of a perjury conviction if he misguesses how a court would decide his case.

128. See text at notes 81-2 supra.

129. "['T] is an improper mode; because it puts the most essential interests of the citizen upon a worse footing than we should be willing to tolerate where inferior interests were concerned; and because... it substitutes for the established and legal mode of investigating crimes and inflicting forfeitures, one that is unknown to the Constitution, and repugnant to the genius of our law." Alexander Hamilton, quoted in Cummings v. Missouri, 4 Wall. 277, 332 (U.S. 1867). 
ing to Madison in The Federalist, that the constitutional prohibition was intended to preserve. ${ }^{130}$ It is this same separation of functions that the Supreme Court ignored in Douds and Garner. ${ }^{131}$ The Court justified its finding of no bill of attainder in those cases by reliance on the relevancy of the conduct proscribed to the deprivations imposed. ${ }^{132}$ But such matters are irrelevant to a constitutional prohibition which has nothing to do with end results but concerns itself solely with the means by which punishment is imposed.

\section{Conclusion}

The Cummings definition of bill of attainder ${ }^{133}$ needs to be restated in a more meaningful form if it is to have any real force in present-day constitutional law. WTe suggest the following: a legislative act which without judicial trial deprives named individuals, or groups easily ascertainable by description or expurgatory oath, of any right or privilege.

Such a restatement is necessary to prevent legislative usurpation of judicial functions. Decisions like Douds ${ }^{134}$ and Garncr, ${ }^{135}$ with their reliance on reasonableness, ${ }^{136}$ have reduced the constitutional prohibition on bills of attainder to a supple reed indeed. The provision is no longer a "bulwark in favor of personal security and private rights" against "the fluctuating policy [of] public councils"137 when that policy is used to justify a finding of no bill of attainder. If the aim of the prohibition is to allow the imposition of punishment only after a judicial finding of guilt, the legislature cannot be permitted to decide who is guilty of what in the guise of protecting the public.13s Otherwise, the fate of every citizen will rest not on the rock of constitutional justice but on the shifting sands of legislative pleasure. ${ }^{133}$

130. The Federalist, No. 44 (Madison) at 299 (Heritage ed. 1945). See also Wormuth, Legislatize Disqualifications as Bills of Aliainder, 4 VArio. L. REv. 603, 604-05 (1951).

131. See Cummings v. Missouri, 4 Wall. 277, 323 (U.S. 1867).

132. See text at notes 59 and 82 supra.

133. "[A] legislative act which inflicts punishment without judicial trial." Cummings v. Missouri, 4 Wall. 277, 323 (U.S. 1867).

134. American Communications Ass'n v. Douds, 339 U.S. 382 (1950).

135. Garner v. Board of Public Works, 341 U.S. 716 (1951).

136. See text at notes 59 and $\$ 2$ suipra.

137. The Feneralist, No. 44 (MIadison) at 299 (Heritage ed. 1945).

138. See note 120 supro.

139. "The accumulation of all powers, legislative, exceutive, and judiciary, in the same hands, whether of one, a few, or many, and whether hereditary, self-appointed, or elective, may justly be pronounced the very definition of tyranny." Tue Feurruarss, No. 47 (Madison) at 322 (Heritage ed. 1945). 